\title{
Delays in construction works in Polish construction industry from the contractors' point of view
}

\author{
Anna Kowalczyk ${ }^{1}$, Wiesław Meszek ${ }^{1}$, Mariusz Rejment ${ }^{2}$ and Agnieszka Dziadosz $^{1 *}$, \\ ${ }^{1}$ Poznan University of Technology, Piotrowo 5 Street, 60-965 Poznan, Poland \\ ${ }^{2}$ Wroclaw University of Science and Technology, Wybrzeże Wyspiańskiego 27, 50-370 Wroclaw, \\ Poland
}

\begin{abstract}
The construction industry is sensitive to changing random conditions that determine the occurrence of various disturbances during the construction investment process. These disturbances are the source of numerous delays during realization of the construction project. The identification of the reasons for delays and their impact on the progress of construction works allows for the efficient management of the construction project and planning of protective measures, which reduce the risk of their occurrence. The purpose of this article is to identify and then to assess, on the basis of the conducted questionnaire survey, the impact of disturbances on delays in construction works. In addition, the factors were ranked in terms of the degree of impact on the construction project by calculating the rank of the factor.
\end{abstract}

\section{Introduction}

Regardless of the scale and complexity of a construction project, the delays are a permanent part in the construction process. By the term "delay" we mean the exceeding of the deadline (set out in the contract) for the execution/completion of construction works, which arises as a result of a defined disturbance. The disturbance is a phenomenon that causes: interruption, prolonging the duration of construction works or postponement of execution of construction works, resulting in a delay in the execution time of construction works.

Due to the random nature of disturbances that have a significant impact on the construction process, the problem of delays in construction industry is readily undertaken by lots of scientists [1-5]. The main area of research, presented in the literature, is the identification of delays, the analysis of the basic causes of delays and the attempt to assess their impact on the construction of a building facility, which is often classified as a risk of time or untimely completion of the construction project [1-14]. The authors, in the article, made an attempt to rank factors due to the degree of influence on delays in the execution of construction works based on the preliminary questionnaire survey carried out in May 2018 among people associated with the construction industry, who perform various functions in

*Corresponding author: agnieszka.dziadosz@put.poznan.pl 
the construction investment process. The research allowed us to receive a full range of factors causing delays in construction works.

\section{Delays in construction works from the contractors' point of view}

\subsection{Structure of the surveyed respondents}

The preliminary questionnaire survey was conducted among contract managers, construction managers, construction engineers, designers and building inspectors in the area of the Greater Poland Voivodeship. The questionnaire surveys forms were sent to 35 randomly selected representatives of construction companies. About $71 \%$ of fully completed survey forms were returned. The structure of the surveyed population, due to the work position, is shown in Figure 1.

The largest number of respondents participated in the construction of public buildings ( $38.3 \%$ of respondents). The second place was occupied by single-family and multi-family residential buildings and a collective residence $(26.8 \%)$. The next item (14.8\%) was taken up by cubature and engineering building facilities related to the industrial construction. Less than $13 \%$ (i.e. $12.6 \%$ ) of the surveyed participants took part in the construction of engineering constructions facilities related to the transportation construction. The engineering construction buildings (associated with municipal buildings) constituted $6.6 \%$ of the surveyed population. Only $1 \%$ of participants participated in the construction of military building facilities. Such a large discrepancy of the constructed building facilities ensures the identification of delays, however, it makes impossible to classify them in relation to the type and type of the constructed building.

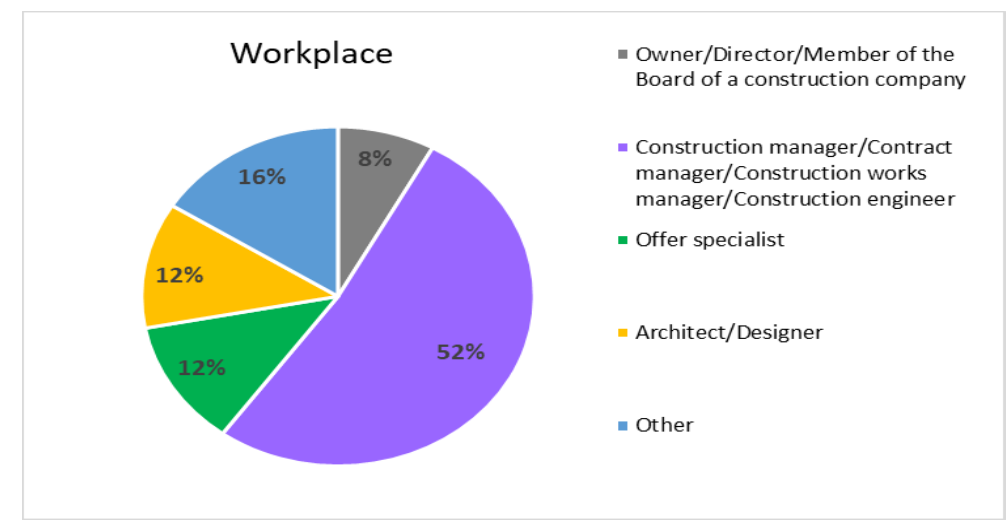

Fig. 1. Structure of the examined population: workplace. Source: authors' data

\subsection{Identification and ranking of factors causing delays}

The main goal of the research was to identify the most important factors and to determine the extent of their impact on the delays of construction works. The key factors are set together in Table 1. The collected results show that in a given period (i.e. in the year 2018) the lack of workers in the market has had a very big influence on delays. This factor was indicated by $60 \%$ of respondents, describing it as "a factor with a very high impact" delaying the completion of construction works. Other factors, that have "a high impact" on delays, are the following: 
- too short deadlines imposed by ordering parties $(60 \%)$,

- deliberate delays in payments (48\%),

- difficulties in financing of construction works by a contractor (48\%),

- inadequate experience of a contractor/designer (44\%),

- delays in the delivery of building materials (36\%).

Table 1. List of factors delaying construction works

\begin{tabular}{|c|c|c|c|c|c|c|c|c|}
\hline & Factor & 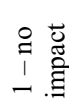 & 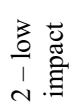 & 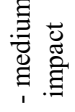 & 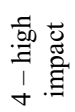 & 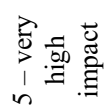 & \multicolumn{2}{|c|}{$\begin{array}{l}\text { Rank of } \\
\text { factor }\end{array}$} \\
\hline & & $\%$ & $\%$ & $\%$ & $\%$ & $\%$ & & \\
\hline 1 & $\begin{array}{l}\text { Lack of constructive } \\
\text { cooperation between an } \\
\text { investor (ordering party) } \\
\text { and a general contractor }\end{array}$ & 4 & 8 & 16 & 44 & 28 & 384 & 3 \\
\hline 2 & Weather conditions & 4 & 16 & 36 & 32 & 12 & 332 & 7 \\
\hline 3 & $\begin{array}{l}\text { Large number of } \\
\text { subcontractors }\end{array}$ & 8 & 16 & 40 & 32 & 12 & 348 & 6 \\
\hline 4 & $\begin{array}{l}\text { Delays in the delivery of } \\
\text { building materials }\end{array}$ & 4 & 12 & 24 & 36 & 24 & 364 & 4 \\
\hline 5 & $\begin{array}{l}\text { Application of very modern } \\
\text { or very old } \\
\text { technologies/construction } \\
\text { techniques }\end{array}$ & 8 & 12 & 64 & 16 & 0 & 288 & 8 \\
\hline 6 & Large construction site & 16 & 28 & 44 & 8 & 4 & 256 & 9 \\
\hline 7 & $\begin{array}{l}\text { Deliberate delays in } \\
\text { payments }\end{array}$ & 4 & 0 & 36 & 48 & 12 & 364 & 4 \\
\hline 8 & $\begin{array}{l}\text { Incorrect/imprecise } \\
\text { construction law }\end{array}$ & 4 & 24 & 52 & 20 & 0 & 288 & 8 \\
\hline 9 & $\begin{array}{l}\text { Too short deadlines } \\
\text { imposed by ordering parties }\end{array}$ & 4 & 0 & 12 & 60 & 24 & 400 & 2 \\
\hline 10 & $\begin{array}{l}\text { Staff changes during the } \\
\text { construction process }\end{array}$ & 8 & 8 & 44 & 24 & 16 & 332 & 7 \\
\hline 11 & Lack of workers & 4 & 4 & 8 & 24 & 60 & 432 & 1 \\
\hline 12 & $\begin{array}{l}\text { Inadequate experience of a } \\
\text { contractor/designer }\end{array}$ & 4 & 8 & 28 & 44 & 16 & 360 & 5 \\
\hline 13 & $\begin{array}{c}\text { Difficulties in financing of } \\
\text { construction works by a } \\
\text { contractor }\end{array}$ & 4 & 4 & 24 & 48 & 20 & 376 & 4 \\
\hline
\end{tabular}

The following factors had the medium impact according to the respondents:

- application of very modern or very old technologies/construction techniques (64\%), 
- incorrect/imprecise construction law (52\%),

- large construction site (44\%),

- staff changes during the construction process (44\%),

- weather conditions (36\%).

From the perspective of hierarchical ranking of factors, it should be noted that:

- $84 \%$ of respondents assessed the impact of the factor "Lack of workers" very high, as well as the factor " Too short deadlines imposed by ordering parties",

- $50 \%$ of respondents rated the factor "Staff changes during the construction process", "Weather conditions" and "Application of very modern or very old technologies/construction techniques" as the factors with a decidedly medium impact or even below,

- according to the respondents, the smallest impact on the delay has the factor "Large construction site" and the related with that factor coordination of construction works.

\section{Conclusions}

In the literature, on this subject, the authors cite many examples of classification of factors causing delays as well as they try to set them into groups. According to the authors of the article, it is worth expanding and refining the nest research, which would allow to determine the impact of the type and specifics of the construction investment, the type of an investor (public, private) and the selected group of participants on the assessment of construction delays. The factors, mentioned in the article, concerned the construction phase of building facility, therefore there are no factor in the respondents' answers, which often appears in the quoted publications, i.e. "difficulties in obtaining the necessary permits, agreements and opinions".

The presented factors are an excellent introduction to the risk analysis and attempt to measure it both in terms of time as well as finances. Each of the identified factors has a different impact on the risk level associated with a given construction contract.

Despite the excellent engineers' knowledge, many tools supporting the management of the construction process and numerous studies on the causes of delays in the construction industry, the phenomenon of delays in construction works is still valid. Therefore, it seems necessary to introduce in the next analyzes the dependence of factors on, for example, the type of investor or the specificity of the building facility being constructed.

\section{References}

1. J. Drzewiecka, J. Pasławski, Bud. i Inż. Środ., 2, 4, 475-479 (2011),

2. M. Dytczak, G. Ginda, T. Wojtkiewicz, Bud. i Inż. Środ., 2, 4, 481-485 (2011)

3. A. Leśniak., E. Plebankiewicz, Zeszyty Naukowe WSOWL, 157, 3, 332-339 (2010)

4. H. Anysz, A. Zbiciak, Autobusy : technika, eksploatacja, systemy transportowe, R. 14, 3, 963-972 (2013)

5. A. Kowalczyk, Posnan Univeristy of Technology, master thesis (2018)

6. A. Dziadosz, M. Rejment, Proc. Eng., 122, 258-265 (2015)

7. A. Dziadosz, A. Kończak, Arch. of Civil Eng., 62 (1), 111-126 (2016)

8. M. Rejment, A. Dziadosz, Zeszyty Naukowe Politechniki Rzeszowskiej. Budownictwo i Inżynieria Środowiska, 59, 3/III, 65-72 (2012)

9. M. Gajzler, A. Dziadosz, P. Szymański, Tech. Trans. (1-B), 2, 107, 71-84 (2010) 
10. Zavadska. T. Vilutiene, Z. Turskis, J. Šaparauskas, Arch. of Civil and Mech. Eng., 14 (1), 114-121 (2014)

11. O. Kapliński, Proc. Eng., 57, 533-539 (2013)

12. T. Kasprowicz, Arch. of Civil Eng. 62 (1), 55-66 (2016)

13. M. Gajzler, K. Zima, Int. J. of Civil Eng., 15, 5, 641-52 (2017)

14. A. Dziadosz, A. Tomczyk, O. Kapliński, Proc. Eng. 122, 120-128 (2015) 